\title{
Examination of Systole/Diastole Ratio of Umbilical Artery in the third Trimester Gestational Pregnancy and its Correlation with Lactate Acid Level in Fetal Cord
}

\author{
Sarma Nursani Lumbanraja ${ }^{1 *}$, Muhammad Rizki Yasnil ${ }^{1}$, Andre Marolop Pangihutan Siahaan² \\ ${ }^{1}$ Department of Obstetrics and Gynaecology, Faculty of Medicine, Universitas Sumatera Utara, Medan, Indonesia; ${ }^{2}$ Faculty of \\ Medicine, Universitas Sumatera Utara, Medan, Indonesia
}

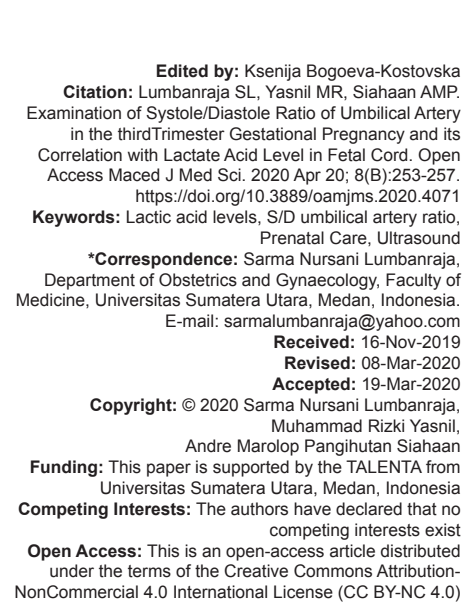

\section{Introduction}

Fetal distress is a serious complication of perinatal infants and refers to fetal hypoxia in the uterus and asphyxia immediately after the baby is born [1], [2]. The occurrence of uteroplacental disorders is related to various factors, including maternal and fetal factors. The umbilical blood flow is an important channel that connects the fetus and the mother, where nutrients and oxygen are delivered by the umbilical artery. When fetal distress occurs, umbilical cord blood flow, and fetal blood flow decrease, which in turn causes fetal circulation and respiratory dysfunction in the womb. This will result in poor fetal outcomes, until the occurrence of neurological disability or infant death [3].

The World Health Organization (WHO) estimates that asphyxia in newborns has occurred between 4 and 9 million annually, which causes up to
1.2 million deaths. In other countries such as India, as many as 49/1000 births occur asphyxia which results in infant mortality [4]. Death of newborns in Indonesia alone is about $27 \%$ due to asphyxia [5].

Evaluating cord blood flow characteristics with ultrasound can provide a reference for prediction and diagnosis of fetal distress, especially by conducting an ultrasound examination of the Doppler S/D ratio of the umbilical arteries especially at gestational age $>30$ weeks [6], [7].

In the previous studies conducted by $\mathrm{Xu}$ et al., RI parameters (resistance index), PI (pulsatility index), and S/D (systolic/diastolic), and central blood flow were evaluated by Doppler ultrasound. In the course of normal pregnancy, the RI parameters (resistance index), PI (pulsatility index), and S/D (systolic/diastolic) decrease gradually with gestational age, gradually reducing resistance, and increasing umbilical arterial 
blood flow. Conversely in abnormal circumstances, S/D ratio of the umbilical artery will increase or experience end diastolic flow or reversed end diastolic flow which indicates a fetal emergency.[8], [9].

The high mortality rate of newborns due to asphyxia shows the high failure in handling and comprehensive prevention of infants, so this research is expected to be a reference for better team preparation in dealing with newborns, where fetal distress can be predicted in advance by examining $S / D$ ratio of umbilical arteries, and research is expected to explain the relationship between the results of S/D ratio of umbilical artery ratio with lactic acid levels where high levels of lactic acid indicate the state of fetal hypoxia [10].

\section{Objective}

The objective of the study was to determine the correlation of umbilical artery SD ratio examination with lactate acid levels in the umbilical cord

\section{Research methods}

This study was an observational analytic study with a cross-sectional study design. The research was conducted in RSUP Haji Adam Malik Medan and Satellite Hospital. The sample was pregnant women who meet the inclusion and exclusion criteria, we found 38 of pregnant women from January to December 2019.

\section{Results and Discussion}

\section{Characteristic of study samples}

From Table 1, the average age of patients in this study was 30 (5) years, the majority of multiparous patients were 25 (47.2), and the average gestational age was

Table 1: Characteristic of sample(s)

\begin{tabular}{ll}
\hline Characteristic & Value \\
\hline Age (mean \pm SD) & $30(5)$ \\
Parity (n,\%) & $14(26,4)$ \\
Primipara & $11(20,8)$ \\
Secundipara & $25(47,2)$ \\
Multipara & $3(5,7)$ \\
Grand multipara & $38(2)$ \\
Gestational age (mean \pm sd) & \\
Delivery method (n,\%) & $15(28,3)$ \\
SVD & $38(71,7)$ \\
C - Section & $2.81(0,52)$ \\
SD Ratio (mean $\pm s d)$ & $2.7(0,4)$ \\
Lactic Acid (mean $\pm s d)$ & \\
Apgar Score (n,\%) & $1(1,9)$ \\
5/6 & $1(1,9)$ \\
$6 / 7$ & $15(28,3)$ \\
$7 / 8$ & $29(54,7)$ \\
$8 / 9$ & $7(13,2)$ \\
$9 / 10$ & \\
\hline
\end{tabular}

38 (2) weeks. Most births in this study were SC 38 (71.7) with an average S/D ratio in the study of $2.81(0.52)$ and a mean lactic acid level of $2.7(0.4)$. The average Apgar score in this study was $8 / 9$ as many as 29 (54.7).

\section{$S D$ ratio with Apgar score in newborn}

Based on Table 2, the average S/D ratio is obtained with the average Apgar score of the patient. From this study, it is known that the higher the Apgar

Table 2: The relationship umbilical artery S/D ratio with Apgar score

\begin{tabular}{llll}
\hline Apgar Score & S/D ratio & & $\mathrm{p}$ \\
\cline { 2 - 3 } & Mean & SD & 0,28 \\
\hline $5 / 6$ & 2.50 & & \\
$6 / 7$ & 2.60 & 0.45 & \\
$7 / 8$ & 2.72 & 0.41 & \\
$8 / 9$ & 2.77 & 0.96 & \\
$9 / 10$ & 3.21 & & \\
\hline
\end{tabular}

score, the higher the average S/D ratio value in patients. The mean patients with poor Apgar outcomes (5/6) have an S/D ratio of 2.5. From the analysis using ANNOVA also obtained, $p=0.28$. This shows that there is no significant relationship between Apgar score and S/D ratio.

\section{newborns}

Lactic acid value with Apgar score in

From Table 3, it was found that an increase in lactic acid was found in infant outcomes with an Apgar score of $9 / 10$ with a mean value of 2.9 (0.5). From the ANNOVA analysis, $p$ value of 0.99 was also found. This

Table 3: The relationship umbilical lactic acid level with Apgar Score

\begin{tabular}{llll}
\hline Apgar score & Lactic acid & & $\mathrm{p}$ \\
\cline { 2 - 3 } & Mean & SD & \\
\hline $5 / 6$ & 2.7 & $\cdot$ & \\
$6 / 7$ & 1.7 &. & 0.99 \\
$7 / 8$ & 2.6 & 0.5 & \\
$8 / 9$ & 2.8 & 0.4 & \\
$9 / 10$ & 2.9 & 0.5 & \\
\hline
\end{tabular}

showed that there was no significant relationship between the levels of lactic acid and Apgar score for infants.

\section{Correlation of lactic acid and S/D ratio with Apgar score of newborn}

In Table 4, it is found that lactic acid has a very weak positive correlation with APGAR score for infants with an $R$ value of $0.274(p=0.047)$, this shows that lactic acid does not have a strong relationship with infant outcomes.

\section{Discussion}

Fetal distress is a risk factor that can cause neonatal asphyxia and perinatal fetal death, and 
Table 4: The correlation umbilical lactic acid level and umbilical artery S/D ratio with Apgar score

\begin{tabular}{|c|c|c|c|c|c|c|c|}
\hline \multirow[t]{3}{*}{ Variable } & \multicolumn{5}{|c|}{ Apgar score } & \multirow[t]{3}{*}{$\mathrm{p}$} & \multirow[t]{3}{*}{$\mathrm{R}$} \\
\hline & $5 / 6$ & $6 / 7$ & $7 / 8$ & $8 / 9$ & $9 / 10$ & & \\
\hline & $\begin{array}{l}\text { Mean } \\
\text { (Sd) }\end{array}$ & $\begin{array}{l}\text { Mean } \\
\text { (Sd) }\end{array}$ & $\begin{array}{l}\text { Mean } \\
\text { (Sd) }\end{array}$ & $\begin{array}{l}\text { Mean } \\
\text { (Sd) }\end{array}$ & $\begin{array}{l}\text { Mean } \\
(\mathrm{Sd})\end{array}$ & & \\
\hline S/D ratio & $2.50(0)$ & $2.60(0)$ & $\begin{array}{l}2.72 \\
(0,45)\end{array}$ & $\begin{array}{l}2.77 \\
(0,41)\end{array}$ & $\begin{array}{l}3.21 \\
(0,96)\end{array}$ & 0,068 & 0,253 \\
\hline $\begin{array}{l}\text { Lactic } \\
\text { acid }\end{array}$ & $2.7(0)$ & $1.7(0)$ & $2.6(0,5)$ & $2.8(0,4)$ & $2.9(0,5)$ & 0,047 & 0,274 \\
\hline
\end{tabular}

newborn survivors will have nerve function damage and sequelae under the influence of long-term intrauterine hypoxia [11]. Based on our research, we found that the average age of patients in this study was 30 (5) years, the majority of multiparous patients were 25 (47.2), and the average gestational age was 38 (2) weeks. Most births in this study were SC 38 (71.7) with an average S/D ratio in the study of $2.81(0.52)$ and a mean lactic acid level of 2.7 (0.4). The average Apgar score in this study was 8/9 as many as 29 (54.7). In clinical practice, early prediction of fetal distress is beneficial for early prevention and intervention, thereby reducing fetal distress from newborns [12]. Abnormal cord blood is a pathological factor and is closely related to fetal distress, abnormal umbilical cord will directly affect the state of umbilical artery flow, and abnormal placental and maternal factors will be complicated by abnormal umbilical artery flow. Therefore, evaluating the characteristics of umbilical artery flow can provide a diagnosis, prediction, and evaluation of fetal distress. Doppler ultrasound is a routine method for prenatal examination, which can not only evaluate fetal growth and development but also quantitatively measure umbilical arterial flow [13]. In this study, ultrasonic analysis of umbilical artery flow parameters in normal pregnant women confirmed that the $\mathrm{RI}, \mathrm{PI}$, and $\mathrm{S} / \mathrm{D}$ of the umbilical artery gradually decreased with prolongation of gestational weeks. Changes in umbilical artery ultrasound are associated with decreased vascular resistance to the placenta, lumen expansion, and increased blood flow, which also reflects that fetal and placental blood perfusion increases with the process of pregnancy [7].

From this study, it is known that the higher the Apgar score, the higher the average $S / D$ ratio value in patients. The mean patients with poor Apgar outcomes $(5 / 6)$ have an S/D ratio of 2.5. From the analysis using ANNOVA also obtained, $p=0.28$. This shows that there is no significant relationship between Apgar score and $S / D$ ratio. During fetal distress, abnormal umbilical arterial flow caused by different pathological factors can affect fetal blood supply and results in ischemic injury due to hypoxia. To determine changes in ultrasound parameters of umbilical artery flow, a puerperal examination was performed in patients with a history of intrauterine fetal hypoxia, with normal pregnancy without any signs of hypoxia, and the results showed that $\mathrm{RI}, \mathrm{PI}$, and S/D of the intrauterine distress group were significantly higher than normal pregnancy group at different stages of pregnancy [14]. This means that resistance to umbilical artery flow increases significantly while blood flow decreases significantly during childbirth with intrauterine hypoxia, which will increase the incidence of ischemic hypoxia in the fetus and this process, will cause accumulation of local lactic acid due to anaerobic conditions [15]. In this study, an increase in lactic acid was found in infant outcomes with an Apgar score of 9/10 with a mean value of $2.9(0.5)$. From the ANNOVA analysis, $p=0.99$ was also found. This showed that there was no significant relationship between the levels of lactic acid and Apgar score for infants.

Accumulation of lactic acid or lactacidemia occurs when there is asphyxia and metabolic acidosis in the fetus. Metabolic acidosis has a more adverse effect on the fetus and is associated with neonatal morbidity, whereas respiratory acidosis has no adverse effect on the fetus. Lactic acid levels can describe fetal hypoxia through indirect examination of tissue hypoxia. Examination of lactic acid levels in hypoxic states becomes very important after several physiological characteristics of lactic acid are found, namely, increased levels of lactic acid after metabolic acidosis [16], [17].

Increased levels of lactic acid in the fetal hypoxic state have toxic effects on brain tissue. Lactic acid buildup can disrupt cellular integrity and can destroy fetal tissue, if it involves vital organs such as brain, heart, kidney, liver, and the fetus will experience severe organ damage. Lactacidemia can cause increased intracranial pressure and necrosis in the brain. In the study of monkeys found the toxic effects of lactic acid on brain tissue. Lactic acid causes edema and necrosis of the tissue. Therefore, detection of lactic acid is becoming increasingly important to prevent early fetal damage. In hypoxia, brain sparing effect mechanism can occur, where blood flow will be prioritized in vital organs such as brain, heart, and adrenal glands; on the contrary, blood flow to muscles, skin, liver, kidneys, and intestine are reduced [7]. Lactic acid can be checked at several different compartments, for example, blood, subcutaneous tissue, or brain fluid [18], [19], [20].

In the rat hypoxia model, lactic acid showed an increase in subcutaneous tissue preceding the decrease in $\mathrm{pH}$ levels. Increased levels of lactic acid make lactic acid an early marker of hypoxia.

In this study, lactic acid had a very weak positive correlation with the Apgar score of infants with an $R$ value of $0.274(p=0.047)$, this indicates that lactic acid did not have a strong relationship with infant outcomes. Accumulation of lactic acid or lactacidemia occurs when there is asphyxia and metabolic acidosis in the fetus. Metabolic acidosis has a more adverse effect on the fetus and is associated with neonatal morbidity, whereas respiratory acidosis has no adverse effect on the fetus. Lactic acid levels can describe fetal hypoxia through indirect examination of tissue hypoxia [7]. Examination of lactic acid levels in hypoxic states becomes very important after it is known several physiological characteristics of lactic acid, i.e., elevated levels of lactic acid occur after metabolic acidosis [16], [17]. 


\section{Conclusion}

We found no correlation between umbilical cord S/D ratio and lactic acid with Apgar score. Lactic acid has a very weak positive correlation with the infant Apgar score with an $R$ value of 0.274 .

\section{Authors Contribution Statement}

SNL, MRY participated in the literature research; SNL, MRY participated in the study design; SNL, MRY participated in data collection; SNL, MRY, AMPS participated in data analysis; SNL, MRY participated in data interpretation; SNL, MRY, AMPS participated in writing; SNL, MRY, AMPS participated in critical revision.

\section{Ethics Statements}

\section{Studies involving human subjects}

The studies involving human participants were reviewed and approved by Institutional Review Board of Universitas Sumatera Utara, Medan, Indonesia. Written informed consent for participation was required for this study.

\section{Data availability statement}

The data used to support the findings of this study are available from the corresponding author upon request.

\section{References}

1. Adanikin Al, Awoleke JO. Clinical suspicion, management and outcome of intrapartum foetal distress in a public hospital with limited advanced foetal surveillance. J Matern Fetal Neonatal Med. 2017;30(4):424-9. https://doi.org/10.1080/14767058.2016 .1174991

\section{PMid:27050656}

2. Kolnik N, Strauss T, Globus O, Leibovitch L, Schushan-Eisen I, Morag I, et al. Risk factors for periventricular echodensities and outcomes in preterm infants. J Matern Fetal Neonatal Med. 2017;30(4):397-401. https://doi.org/10.1080/14767058.2016.11 74684

\section{PMid:27046804}

3. Haşmaşanu MG, Bolboaca SD, Drugan TC, Matyas $M$ Zaharie GC. Parental factors associated with intrauterine growth restriction. Srp Arh Celok Lek. 2015;143(11-12):701-6. https://doi.org/10.2298/sarh1512701h

\section{PMid:26946765}

4. Committee on Obstetric Practice, American College of Obstetricians and Gynecologists. ACOG committee opinion. Number 326, December 2005. Inappropriate use of the terms fetal distress and birth asphyxia. Obstet Gynecol. 2005;106(6):1469-70. https://doi. org/10.1097/00006250-200512000-00056

PMid:16319282

5. Yulifah R, dan Yuswanto TJ. Asuhan Kebidanan Komunitas. Jakarta: Salemba Medika; 2009.

6. Mendes RF, Martinelli S, Bittar RE, Francisco RP, Zugaib M. Relation between nucleated red blood cell count in umbilical cord and the obstetric and neonatal outcomes in small for gestational age fetuses and with normal doppler velocimetry of umbilical artery. Rev Bras Ginecol Obstet. 2015;37(10):455-9. https://doi.org/10.1590/so100-720320150005271 PMid:26313882

7. Akolekar R, Syngelaki A, Gallo DM, Poon LC, Nicolaides KH Umbilical and fetal middle cerebral artery Doppler at 35-37 weeks' gestation in the prediction of adverse perinatal outcome. Ultrasound Obstet Gynecol. 2015;46(1):82-92. https:// doi.org/10.1002/uog.14842

PMid:25779696

8. Frauenschuh I, Wirbelauer J, Karl S, Girschick G, Rehn M, ZollnerU, et al. Prognostic factors of perinatal short-term outcome in severe placental insufficiency using Doppler sonography to assess end-diastolic absent and reverse blood flow in umbilical arteries. Z Geburtshilfe Neonatol. 2015;219(1):28-36. https:// doi.org/10.1055/s-0034-1394387 PMid:25734475

9. Wei D, Xu Y, Ma X, Zhang L, Zhu M. Ultrasonic characteristics and clinical significance of umbilical cord blood flow in acute fetal distress. J Acute Dis. 2016;5(6):483-7. https://doi.org/10.1016/j. joad.2016.07.003

10. Ensing S, Abu-Hanna A, Roseboom TJ, Repping S, van der Veen F, Mol BW, et al. Risk of poor neonatal outcome at term after medically assisted reproduction: A propensity scorematched study. Fertil Steril. 2015;104(2):384-90. https://doi. org/10.1016/j.fertnstert.2015.04.035 PMid:26028279

11. Soothill PW, Nicolaides $\mathrm{KH}$, Rodeck $\mathrm{CH}$, Campbell S. Effect of gestational age on fetal and intervillous blood gas and acidbase values in human pregnancy. Fetal Ther. 1986;1(4):168-75. https://doi.org/10.1159/000262264 PMid:3454532

12. Gomella TL. Perinatal asphyxia. In: Gomella TL, Cunningham MD, Eyal FG, editors. Neonatology: Management, Procedures, On-call Problems, Diseases, and Drugs. $6^{\text {th }}$ ed. New York: McGraww-Hill; 2009. p. 624-35

13. Hecher K, Hackeloer BJ. Cardiotocogram compared to Doppler investigation of the fetal circulation in the premature growth-retarded fetus: Longitudinal observations. Ultrasound Obstet Gynecol. 1997;9(3):152-61. https://doi. org/10.1046/j.1469-0705.1997.09030152.x PMid:9165678

14. Kosim MS. Gangguan napas pada bayi baru lahir. In: Kosim MS Yunanto A, Dewi R, Sarosa G, Usman A, editors. Buku Ajar Neonatologi. Jakarta: IDAI; 2008. p. 126-45.

15. Manoe V, Amir I. Gangguan fungsi multi organ pada bayi asfiksia berat. Sari Pediatr. 2005:5(2):72-8. https://doi.org/10.14238/ sp5.2.2003.72-8

16. Orozco-Gregorio $H$, Mota-Rojas $D$, Alonso-Spilsbury $M$, González-Lozano M, Trujillo-Ortega M, Olmos-Hernández S, et al. Importance of blood gas measurements in perinatal asphyxia and alternatives to restore the acid base balance status to improve the newborn performance. Am J Biochem Biotechnol. 
2007;3(3):131-40. https://doi.org/10.3844/ajbbsp.2007.131.140

17. Horne $M$, Heit $U$, Swearingen $H$. Pocket Guide to Fluid, Electrolyte, and Acid-base Balance. Missouri: Mosby-Year Book Inc.; 1997.

18. Smith J, Wells L, Dodd K. The continuing fall in incidence of Hypoxic-ischaemic encephalopathy in term infants. BJOG. 2000;107(4):461-6. https://doi. org/10.1097/00006254-200010000-00010 PMid:10759262

19. Vintzileos A, Nochimson D, Guzman E, Knuppel R,
Lamke M, Schifrin B. Intrapartum electronic fetal heart rate monitoring versus intermittent auscultation: A metaanalysis. Obstet Gynecol. 1995;85(1):149-55. https://doi. org/10.1016/0029-7844(94)00320-d

PMid:7800313

20. Goodwin TM, Milner-Masterson L, Paul RH. Elimination of fetal scalp blood sampling on a large clinical service. Obstet Gynecol. 1994;83(6):971-4. https://doi. org/10.1097/00006250-199406000-00015

PMid:8190443 